\title{
PENGARUH LAMA PEMANASAN TERHADAP KADAR ALKOHOL PADA NIRA SIWALAN (Borassus flabellifer)
}

\author{
Siti Mardiyah ${ }^{1}$ \\ ${ }^{1)}$ Prodi D3 Analis Kesehatan, FIK, Universitas Muhammadiyah Surabaya \\ sitimardiyahfix2@gmail.com
}

Tangal Submit:

27 November 2017

Tanggal Review:

8 Desember 2017

Tanggal Publish Online: 12 Desember 2017

\begin{abstract}
Nira is a raw material for the manufacture of liquid brown sugar, palm sugar, and alcoholic beverages. Among these products are the most widely used alcoholic beverage. During this siwalan juice as a beverage consumed fresh, the storage period is relatively short whice for 1-2 days. If after 3 days the beverage is consumed will have a negative impact, to reduce the alcohol content is then made warming. Based on the above background can be taken formulation of the problem "whether there was an effect on levels of alcohol prolonged heating on sap siwalan"?. The purpose of this study was to determine whether there was an effect on levels of alcohol prolonged heating on sap siwalan. This research is a kind of experimental research with the aim to determine the effect of prolonged heating of the alcohol content in the sap siwalan. The sampling technique used was random sampling, totaling 24 samples. Variable work was composed of independent variables and the dependent variable. Alcohol Examination conducted on sap siwalan by doing without heating or 0 minutes, 10 minutes, 20 minutes and 30 minutes, using a number of methods Pycnometer six replication. From these results a decrease in the average alcohol content of sap siwalan on any heating for $10 \mathrm{~min}, 20 \mathrm{~min}$ and $30 \mathrm{~min}$, after using ANOVA statistical test obtained $\mathrm{p}=0.000(\mathrm{p}<0.05)$ can be summed $\mathrm{Ha} \mathrm{Ho}$ is rejected or accepted which means there is prolonged heating effect on levels of alcohol in the juice siwalan.
\end{abstract}

Keywords: Nira, Level of alcohol, prolonger heating

\section{PENDAHULUAN}

Nira adalah cairan yang keluar dari bunga kelapa atau pohon penghasil nira lain seperti aren, siwalan dan lontar yang disadap. Cairan ini merupakan bahan baku untuk pembuatan gula. Nira sering juga disebut "legen", kata ini sebenarnya istilah bahasa Jawa berasal dari kata legi artinya manis. Dalam keadaan segar nira mempunyai rasa manis berbau harum dan tidak berwarna.
Selain bahan baku pembuatan gula, nira dapat pula digunakan sebagai bahan makanan lain yaitu minuman keras (tuak), asam cuka dan minuman segar, serta pada akhir-akhir ini muncul produk baru dari nira aren yaitu gula merah serbuk (Gusti, 2010).

Dalam proses penyadapan nira ini perlu penanganan, baik sebelum penyadapan maupun sesudah penyadapan. Hal ini karena 
nira merupakan cairan yang mengandung kadar gula tertentu, yaitu sukrosa, glukosa, fruktosa serta karbohidrat, yang memiliki derajat keasaman rata-rata $6-7$ dan berbau harum. Bila nira disimpan maka akan terjadi fermentasi oleh adanya mikroorganisme yang terdapat dalam nira sehingga menyebabkan rasa asam karena terbentuknya asam asetat dan merupakan media yang baik untuk pertumbuhan mikroorganisme seperti bakteri, kapang maupun khamir. Walaupun cairan yang keluar dari bunga steril, namun kerusakan nira dapat terjadi sejak saat ditampung pada bumbung atau pada waktu nira tersebut disadap dari pohon juga pada waktu nira disimpan untuk menunggu waktu pengolahan. Oleh karena itu nira harus segera diolah setelah diambil dari pohon, paling lambat 90 menit setelah dikeluarkan dari bumbung (Gusti, 2010).

Sejauh ini pemanfaatan nira siwalan masih sangat terbatas baik meliputi pengambilan niranya untuk dibuat menjadi gula merah, gula semut, minuman beralkohol. Diantara produk tersebut yang paling banyak diolah petani adalah produk gula merah dan minuman beralkohol. Selama ini nira siwalan dikonsumsi masyarakat sebagai minuman segar, dengan jangka waktu penyimpanan yang relatif singkat yaitu selama 1-2 hari. Apabila setelah 3 hari minuman tersebut jika dikonsumsi akan berdampak negatif karena dapat memabukkan, penyimpanan nira dapat mengakibatkan meningkatnya aktivitas enzim yang ada didalam nira terutama enzim glukokinase, enzim fofoglukoisomerase, enzim fosfofrutokinase, enzim aldolase, enzim gliseraldehida-3 Pdehidrogenase, enzim fosfogliseril kinase, enzim enolase, enzim piruvat kinase, enzim piruvat dekarboksilase, enzim dehidrogenase alkohol dan enzim acetobacter acetic sehingga dapat mempercepat terjadinya proses fermentasi (Sholikhah, 2010).

Kenaikan aktifitas enzim- enzim tersebut membuat kadar alkohol terus bertambah sampai 5-6 \% dan akhirnya berkurang, sedangkan kadar asamnya akan terus bertambah. Untuk mengurangi kadar alkohol ini maka di lakukan pemanasan. Proses pemanasan ini dilakukan untuk menghambat fermentasi dari mikroorganisme. Jika proses fermentasi mikroorganisme terhambat, maka kadar alkohol juga akan berkurang. Sel- sel spora mikroorganisme berbeda dalam hal ketahanannya terhadap suhu tinggi. Jumlah spora yang lebih banyak daripada sel, maka panas yang diperlukan untuk mematikan lebih banyak (Hidayat, et al, 2006).

Pada penelitian yang telah dilakukan sebelumnya menyatakan bahwa cairan nira yang diproduksi dari bahan baku yang mengandung pati dan gula melalui tahap proses fermentasi alkoholik pada suhu kamar 26 0C. Pada penelitian tersebut diperoleh kandungan etanol 4,3586\% dan asam asetat 4 \% pada waktu 28 jam (Rahman, 1992 ).

Dari uraian dan latar belakang masalah diatas, maka permasalahan dalam penelitian 
ini dapat dirumuskan sebagai berikut, Apakah Lama Pemanasan Memberikan Pengaruh Terhadap Kadar Alkohol Pada Nira Siwalan (legen). Tujuan Penelitian Untuk mengetahui ada dan tidaknya pengaruh lama pemanasan terhadap kadar alkohol pada nira siwalan. Manfaat Penelitian Bagi Masyarakat Diharapkan hasil penelitian ini akan dapat bermanfaat dan memberikan informasi tentang kadar alkohol pada nira siwalan setelah pemanasan.

\section{METODE PENELITIAN}

Jenis penelitian ini menggunakan rancangan eksperimental dengan tujuan untuk mengetahui pengaruh lama pemanasan terhadap kadar alkohol pada nira siwalan. Populasi penelitian ini adalah nira siwalan yang diambil langsung dari para penyadap nira siwalan yang berada didesa Sendang, Kecamatan Paciran, Kabupaten Lamongan. Sampel yang digunakan dalam penelitian ini adalah nira siwalan yang sering dikonsumsi oleh masyarakat yang dijual oleh penyadap nira siwalan di desa Sendang, Kecamatan Paciran, Kabupaten Lamongan. Dalam penelitian ini, untuk setiap perlakuan dilakukan masing- masing sebanyak 4 perlakuan dan 6 pengulangan.

Lokasi pengambilan sampel dilakukan didesa sendang Kecamatan Paciran Kabupaten Lamongan.Lokasi Pemeriksaan SampelLokasi pemeriksaan sampel dilakukan di Balai Penelitian dan Konsultasi Industri (BPKI) Surabaya - jawa timur. Lokasi pengolahan data dilakukan di Universitas Muhammadiyah Surabaya dan sekitarnya. waktu Penelitian : Penelitian ini dilaksanakan pada bulan Februari sampai dengan Juli 2012.

Variabel bebas dalam penelitian ini adalah lama pemanasan. Lama pemanasan nira siwalan dilakukan pada suhu $70^{\circ}$ selama 0 menit, 10 menit, 20 menit, 30 menit. Variabel terikat dalam penelitian ini adalah kadar alcohol, Kadar alkohol adalah kadar yang terdapat pada nira siwalan yang dinyatakan dalam (\%) dan ditentukan menggunakan metode Piknometer.

\subsection{Metode Pengumpulan Data}

Data kadar alkohol yang diperoleh dengan cara observasi tidak langsung menggunakan seperangkat uji laboratorium. Pemeriksaan ini menggunakan metode Piknometer. Langkah pemeriksaan kadar alkohol sebagai berikut :

\section{A. Prinsip Pemeriksaan}

Penetapan berat jenis dengan suhu tertentu dari larutan uji setelah dilakukan proses destilasi dan kadar alkohol ditetapkan berdasarkan tabel yang menggambarkan hubungan antara berat jenis dan kadar alkohol. ( Sriwulan, 2002)

B. Alat- alat, Labu destilasi, Pendingin Leibig, Labu ukur, Timbangan Analitik, Beaker glass, Pipet Volume, Gelas ukur, Waterbath, Termometer, Piknometer

\section{Prosedur penentuan kadar alkohol}

1. Perlakuan Sampel, Nira siwalan ditentukan volumenya sebanyak $100 \mathrm{ml}$, Nira 
siwalan dipanaskan di waterbath pada suhu $70^{0}$ selama 0 menit, 10 menit, 20 menit, 30 menit. Setelah proses pemanasan, bahan yang telah dipanaskan dibiarkan sampai dingin, baru kemudian dilanjutkan pada proses destilasi. Memipet bahan $25 \mathrm{ml}$, lalu dimasukkan kedalam labu destilasi. Menambahkan aquadest sampai volume 100 ml. Kemudian didestilasi. Menampung hasil destilasi pada labu ukur $25 \mathrm{ml}$. Dilanjutkan dengan uji penetapan kadar alkohol dengan menggunakan piknometer.

\section{Penentuan kadar alkohol}

a. Berat aquadest : Piknometer kosong yang telah dikeringkan dengan tissue kemudian ditimbang pada suhu kamar $28^{\circ} \mathrm{C}$. Misal: berat piknometer a gram. Piknometer kosong yang sudah ditimbang lalu diisi aquadest, dikeringkan dengan tissue, kemudian ditimbang pada suhu kamar $28^{\circ} \mathrm{C}$. Misal: berat piknometer b gram. Berat aquadest dinyatakan dengan: Berat piknometer isi aquadest -berat piknometer kosong : b gram a gram.

b. Berat alkohol : Piknometer yang sudah dikosongkan lalu dikeringkan dengan tissue, lalu diisi dengan hasil destilasi (penyulingan) dan ditimbang pada suhu kamar $28^{\circ} \mathrm{C}$.Misal: berat piknometer c gram. Berat alkohol dinyatakan dengan: Berat piknometer isi cairan sampel - berat piknometer kosong : c gram - a gram

c. Untuk mengukur specivic gravity digunakan rumus:

$$
\begin{aligned}
\mathrm{SG} \text { alkohol }= & \frac{\text { Berat alkohol }}{\text { Berat aquades }} \\
& =\frac{\mathrm{c}-\mathrm{a}}{\mathrm{b}-\mathrm{a}} \\
& =\mathrm{X} \text { (lihat tabel) }
\end{aligned}
$$

Setelah diperoleh nilai specific gravitynya pada suhu tertentu, lalu dibandingkan dalam tabel alkohol sehingga diketahui konsentrasi alkohol dalam sampel.

\section{HASIL PENELITIAN}

Dari hasil pemeriksaan kadar alkohol pada nira siwalan dengan lama pemamasan 0 menit, 10 menit, 20 menit dan 30 menit dengan menggunakan metode piknometer yang dilakukan di Balai Penelitian dan Konsultasi Industri laboratorium (BPKI) Surabaya, didapatkan hasil sebagai berikut :

Tabel 1. Hasil Pemeriksaan Kadar Alkohol Pada Nira Siwalan

\begin{tabular}{|c|c|c|c|c|}
\hline \multirow{2}{*}{ Sampel } & \multicolumn{4}{|c|}{ Kadar alkohol dalam } \\
\cline { 2 - 5 } & $\begin{array}{c}0 \\
\text { menit }\end{array}$ & $\begin{array}{c}10 \\
\text { menit }\end{array}$ & $\begin{array}{c}20 \\
\text { menit }\end{array}$ & $\begin{array}{c}30 \\
\text { menit }\end{array}$ \\
\hline 1 & 6,70 & 6,55 & 6,32 & 6,25 \\
\hline 2 & 6,85 & 6,02 & 5,07 & 4,63 \\
\hline 3 & 7,07 & 5,95 & 5,29 & 4,72 \\
\hline 4 & 7,15 & 5,80 & 4,93 & 4,28 \\
\hline 5 & 6,92 & 5,66 & 5,14 & 4,64 \\
\hline 6 & 6,55 & 6,10 & 5,00 & 4,50 \\
\hline Total & 41,24 & 36,08 & 31,75 & 29,12 \\
\hline Rata- & 6,87 & 6,01 & 5,29 & 4,85 \\
rata & & & & \\
\hline
\end{tabular}

Kadar alkohol pada nira siwalan dengan tanpa pemanasan 0 menit diperoleh kadar 
alkohol terkecil 6,55\%, terbesar 7,15\%, dengan pemanasan selama 10 menit diperoleh kadar alkohol terkecil $5,66 \%$ terbesar $6.55 \%$, dengan pemanasan selama 20 menit diperoleh kadar alkohol terkecil 4,93\% terbesar 6,32\%, sedangkan dengan pemanasan selama 30 menit kadar alkohol terkecil 4,28\% dan yang terbesar $6,25 \%$.

Dari data pemanasan 0 menit sampai dengan 30 menit diperoleh nilai rata-rata kadar alkohol sampel pada pemanasan 0 menit $6,87 \%$; pada 10 menit $6,01 \%$; pada 20 menit $5,29 \%$; dan pada 30 menit 4,8\%. Sehingga semakin lama pemanasan pada nira siwalan maka kadar alkoholnya akan semakin rendah.

Adapun rata- rata kadar alkohol dapat dilihat seperti pada gambar 1 .

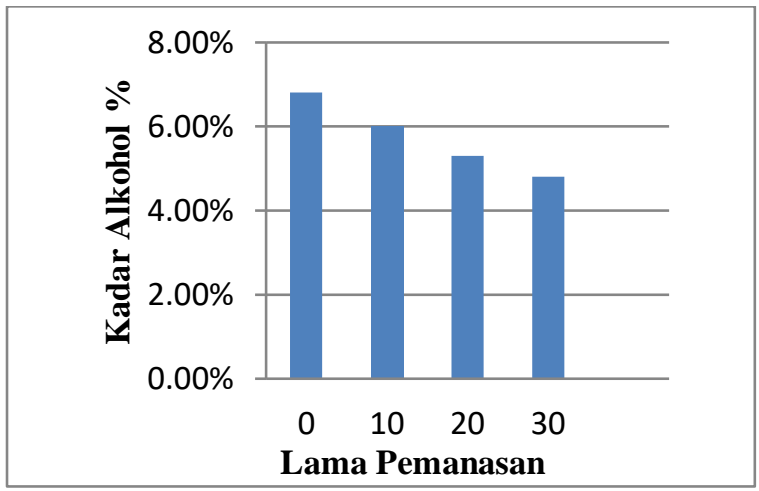

Gambar 1. Grafik Kadar Alkohol

Setelah mendapatkan hasil pemeriksaan kadar alkohol pada nira siwalan, kemudian dilanjutkan dengan melakukan uji distribusi normal maka dilanjutkan lagi dengan melakukan uji ANOVA untuk mendapatkan hasil akhir kadar alkohol pada nira siwalan. Hasil uji distribusi normal dengan menggunakan uji kolmogorov didapatkan signifikan $\mathrm{P}=0,839$ sehingga datanya terdistribusi normal. Hal ini ditunjukkan dengan tingkat signifikan $\mathrm{p}>0,05$. Dari hasil uji ANOVA didapatkan signifikan $\mathrm{p}=0,000$. Dengan demikian dapat disimpulkan bahwa Ho ditolak atau Ha diterima yang berarti ada pengaruh lama pemanasan terhadap kadar alkohol selama 0 menit, 10 menit, 20 menit dan 30 menit dengan signifikan $\mathrm{p}=0,000(\alpha<$ 0,05 ). Jadi $\mathrm{H}$ alternative diterima. Hal ini ditunjukkan dengan tingkat signifikan dibawah $0,05(5 \%)$.

\section{PEMBAHASAN}

Berdasarkan penelitian yang dilakukan tersebut alkohol di dalam legen bisa dihilangkan dengan memberikan pemanasan < 800 C. Rata- rata kadar alkohol yang di dapat dengan pemanasan 0 menit, 10 menit, 20 menit dan 30 menit berturut - turut adalah $6,87 \%, 6,01 \%, 5,29 \%$, dan $4,85 \%$.

Dari hasil uji ANOVA diperoleh dengan taraf signifikan $\mathrm{p}(0,000)<\alpha(0,05)$. Sehingga semakin lama pemanasan nira siwalan akan semakin rendah kadar alkoholnya.

Pada mikroba yang masih berada pada fasa stasioner atau disebut fase adaptasi. Fase ini mikroba lebih berusaha menyesuaikan diri dengan lingkungan dan medium baru dari pada tumbuh ataupun berkembang biak. Mikroba berusaha merombak materi-materi dalam medium agar dapat digunakan sebagai nutrisi untuk pertumbuhannya. Pada waktu tanpa pemanasan terdapat kenaikan rata- rata kadar alkohol yang relatif meningkat yaitu $6,87 \%$ hal 
ini terjadi karena pada waktu pendiaman ini mikroba mengalami pertumbuhan yang cepat, dimana fase ini mikroba sudah dapat menggunakan nutrisi dalam medium fermentasinya dan pada fase ini mikroba banyak tumbuh dan membelah diri sehingga jumlahnya meningkat dengan cepat. Setelah waktu pemanasan, kenaikan kadar yang diperoleh tidak terlalu banyak mengalami peningkatan atau relatif landai. Penurunan yang relatif landai terjadi pada waktu pemanasan selama 10 menit, 20 menit, dan 30 menit yaitu ini dimungkinkan akhir pertumbuhan mikroba pada nira siwalan ini, yang merupakan fase eksponensial dimana fase ini laju pertumbuhan tetap pada laju pertumbuhan maksimum. Seiring dengan pertumbuhan yang maksimum pada fase ini ada sebagian kecil mikroba yang mulai mengalami kematian yang ditunjukkan pada pemanasan selama 30 menit sedikit mengalami penurunan yaitu rata- rata kadar alkohol $4,85 \%$.

Pemanasan yang dilakukan bertujuan untuk mengurangi populasi mikroorganisme atau membunuhnya yang ada didalam bahan pangan. Perlakuan pemanasan sering dikombinasikan dengan perlakuan lainnya untuk mencegah rekontaminasi oleh adanya mikroorganisme. Sel - sel spora berbeda dalam sel ketahanannya terhadap suhu tinggi, jumlah spora yang lebih banyak daripada sel, maka panas yang dibutuhkan untuk mematikan lebih banyak (Hidayat, et al, 2006).
Pada proses tersebut menggunakan suhu optimum yakni pada suhu $70^{\circ} \mathrm{C}$ karena dimungkinkan adanya aktifitas berbagai macam mikroorganisme yang menyebabkan timbulnya kadar alkohol. Jika dipanaskan pada suhu lebih dari $80^{\circ} \mathrm{C}$ dikhawatirkan akan cepat menguap dan berkurang karena merupakan titik didih alkohol.

\section{KESIMPULAN / CONCLUSSION}

Dari hasil penelitian pengaruh lama pemanasan terhadap kadar alkohol pada nira siwalan dapat disimpulkan bahwa, Ada pengaruh lama pemanasan terhadap kadar alkohol pada nira siwalan waktu yang digunakan dengan tanpa pemanasan, 10 menit, 20 menit, dan 30 menit, ditunjukkan dengan penurunan kadar alkohol. Rata- rata kadar alkohol pada nira siwalan yang telah dilakukan tanpa pemanasan 0 menit diperoleh kadar alkohol terkecil 6,55\%, terbesar 7,15\%, dengan pemanasan selama 10 menit diperoleh kadar alkohol terkecil 5,66\% terbesar $6.55 \%$, dengan pemanasan selama 20 menit diperoleh kadar alkohol terkecil 4,93\% terbesar 6,32\%, sedangkan dengan pemanasan selama 30 menit kadar alkohol terkecil 4,28\% dan yang terbesar $6,25 \%$.

Saran Bagi Konsumen Dalam mengkonsumsi nira siwalan Perlu diperhatikan lama penyimpanannya, karena apabila dibiarkan terlalu lama nira siwalan akan menjadi semakin asam dan memungkinkan timbulnya alcohol. Bagi penjual untuk lebih memperhatikan cara pengolahanya agar tidak 
cepat menjadi kadar alkoholnya semakin tinggi maka segera dilakukan adanya perlakuan. Untuk peneliti selanjutnya agar meneliti tentang bakteri apa saja yang terkandung dalam nira siwalan yang menghasilkan alkohol.

\section{DAFTAR PUSTAKA}

Anonim. 2008 Peraturan Menteri Kesehatan RI NO. 86/ Men. Kes/ Per/ IV/77 tentang : Bahan Tambahan Makan Direktorat Pengawasan Obat dan Makanan, Departemen Kesehatan RI. Jakarta

Arintawati. 2006. Mengenal minuman beralkohol.

http://www.republika.co.id.

Diakses tanggal 06 April 2012.

Buckle, K. A, Edwards, R.A, Fleet, G.H. and Wooton, M. 1985. Ilmu Pangan. UIPress. Jakarta.

Estu Patriyatno, S. 2006. Keunikan legen. http://.id.wikipedia.org/wiki/Siwalan . Diakses tanggal 14 Maret 2012.

Ferdiaz. 1992. Mikrobiologi Pangan 1. PT. Gramedia Utama Pustaka. Jakarta.

Frisna, 2008. Reaksi- reaksi senyawa karbon, http : // kimia, upl. Edu/ bahan ajar/ reaksi_organik/ index, htm, diakses : 24 April 2012

Gusti, diah, 2010, Isolasi gasohol dari limbah nira aren (Arenga pinnata merr) Jurnal Penelitian Kelapa. Vol.2 N0.2.

Hidayat, dkk. 1997. Mikrobiologi Industri. Yogyakarta: Penerbit Andi.
Irine Rizki C dkk, 2006. Tuak dan Legen, http :// $\quad$ www.id.wikipedia. org/wiki/siwalan. Diakses : 17 Mei 2012

Joseph, G.H.M.M, M. Rumokoi dan Z. Mahmud. 1990. Perbaikan teknik penyadapan nira lontar di Nusa Tenggara Timur. Buletin Balitka No. 11 Thn 1990 hlm. 103 - 111, Balai Penelitian Kelapa. Manado.

Lempang, M., A. Kadir, W. dan Misdarti. 2003. Teknologi pengolahan nira aren untuk produk nata pinnata. Buletin No.6 Thn. 2003 Badan Penelitian dan Pengembangan Daerah Propinsi Sulawesi Selatan. Makassar.

Mahmud, Z., D. Allorerung dan Amrizal, 1991. Prospek tanaman kelapa, aren, lontar dan gewang, untuk menghasilkan gula. Buletin Balitka No. 14 Thn. 1991 hlm. 90 - 105. Balai Penelitian Kelapa. Manado.

Rukmana. 1998. Ganyong budidaya dan pasca panen. Yogyakarta: Kanisius

Sunanto H. 1993. Aren (Budidaya dan Multigunanya). Yogyakarta : Kanisius

Sriwulan, wieke. 2002. Penuntun praktikum kimia makanan dan minuman. Surabaya

Sudjana. 1996, Metoda satistika. Edisi 6. Bandung : Kanisius

Widjanarko. 2008. Siwalan dan kandungan niranya. $\quad$ http://www.lintas berita.com diakses tanggal 14 Mei 2012.

Wikipedia, 2010. Etanol, http://www.wikipedia.org. diakses tanggal 28 Mei 2012. 